ACTA AGROBOTANICA

Vol. 62 (2): 241-247

2009

\title{
THE CONSEQUENT INFLUENCE OF CROP ROTATION AND SIX-YEAR-LONG SPRING BARLEY MONOCULTURE ON YIELDS AND WEED INFESTATION OF WHITE MUSTARD AND OATS
}

\section{Cezary Kwiatkowski}

\author{
University of Life Science, Department of Tillage and Plant Cultivation, \\ Akademicka 13, 20-950 Lublin, Poland \\ e-mail: czarkw@ poczta.onet.pl
}

Received: 7.04.2009

\section{Abstract}

The present study was conducted in the years 20072008, after 6-year-long experiments in the cultivation of spring barley in a crop rotation system and in monoculture. The other experimental factor was the spring barley protection method. Intensive protection involved comprehensive treatment of barley (in-crop harrowing, seed dressing, application of herbicides, fungicides, a retardant and an insecticide). Extensive protection consisted only in in-crop harrowing, without the application of crop protection agents, except for seed dressing. The above mentioned factors formed the background for the study on the cultivation of white mustard and oats, as phytosanitary species, in successive years. In the test plants, no mineral fertilization and crop protection were applied. Such agricultural method enabled an objective assessment of the consequent effect of monoculture, crop rotation and crop treatments. A hypothesis was made that the cultivation of the phytosanitary plants in the stand after 6-year-long barley monoculture would allow obtaining the level of yields and weed infestation similar to those of the crop rotation treatments. It was also assumed that the cultivation of white mustard and oats would eliminate differences in plant productivity caused by the negative influence of extensive protection.

It was proved that the cultivation of the phytosanitary plants eliminated the negative influence of monoculture on the level of their yields and weed infestation. However, the test plants did not compensate negative consequences of extensive protection. In spite of this, white mustard and oats effectively competed with weeds, and the number and weight of weeds in a crop canopy did not cause a dramatic decline in yields. In the test plant canopy, the following short-lived weeds were predominant: Chenopodium album, Galinsoga parviflora, Echinochloa crus-galli. The absence of herbicide application resulted in the compensation of perennial species: Elymus repens and Cirsium arvense.

Key words: spring barley, monoculture, crop rotation, protection method, consequent influence, white mustard, oats, yielding, weed infestation

\section{INTRODUCTION}

In crop rotations with large cereal proportions, in particular in monoculture, there occur a number of negative phenomena resulting, among other things, in a decline in competitiveness of crop plants relative to weed flora. Increased weed infestation of a crop canopy is in turn one of the main reasons for their reduced productivity ( $\mathrm{Deryło}$ and $\mathrm{Paw}$ ow ski, 1982; Deryło, 1994). Spring barley is a species sensitive to monoculture and related weed pressure (W e s o ł ow s ki et al. 2003; B le c h a r c z y k et al. 2005). Proper crop sequencing, based on environmental factors, coupled with appropriate agricultural practices applied with it, ensures to a large extent a successive increase in yields and a reduction in weed infestation (Z a w iśl a k, 1997; A d a mi a k, 2007). In the opinion of some authors (K w i a t k o w s k i, 2004a; Stupnicka-Rodzynkiewicz et al. 2004), comprehensive mechanical and chemical protection of spring barley only partially compensates the effects of inappropriate crop sequencing. The cultivation of phytosanitary plants (mustard, oats) can be included among factors which reverse the negative effects of barley or wheat monoculture. As shown by the studies of O les ze k (1994) and M u r a w a et al. (2004), white mustard, thanks to certain peculiar allelopathic substances, may inhibit germination and even growth of some weed species in a natural way. Oats, compared to other cereals, reacts weaker to monoculture and its cultivation after other grain plants. In strongly cerealbased crop rotations, it may perform the role of a phytosanitary and regenerating plant (Jelinowski, 1979; Adamiak, 1992; Adamiak and Adami a k, 1994).

The above arguments allowed us to make a hypothesis that the cultivation of white mustard and 
oats in successive years in the stand after 6-year-long spring barley monoculture would enable the regeneration of this stand (the level of yields and weed infestation) similar to that obtained in treatments with the consequent influence of crop rotation. An assumption was also made that the cultivation of the phytosanitary plants would eliminate differences in plant productivity and weed infestation, associated with the consequent effect of two protection levels.

The aim of the present study was to assess the condition of weed flora in a white mustard and barley canopy as well as to analyse yields of these species grown for seeds, under different conditions of longterm crop succession and under different crop protection methods.

\section{MATERIALS AND METHODS}

Field investigations were conducted in the years 2007-2008 after 6-year-long (2001-2006) experiments in the cultivation of spring barley in a crop rotation system and in monoculture. A strict field experiment was established at the Czesławice Experimental Farm, belonging to the University of Life Sciences in Lublin, Poland, using the split-plot method in 3 replicates in plots with an area of $27 \mathrm{~m}^{2}$. The experiment was set up on grey-brown podzolic soil formed from loess (soil quality class II). the study:

The following factors formed the background of

I. Crop sequence:

A. crop rotation (potato $^{\mathrm{xx}}-$ spring barley - horse bean - winter wheat),

B. 6-year-long spring barley monoculture.

II. Spring barley protection method:

a. intensive: harrowing before emergence and at the 3-4 leaf stage, seed dressing - Raxil 060 FS (tebuconazol), application of herbicides - Chwastox Turbo 340 SL $(M C P A+$ dicamba) and Puma Uniwersal 069 EW (fenoxaprop-P-ethyl + mefenpyr-diethyl), fungicides - Tilt Plus 400 EC (propiconazole + fenpropidin) and Alert 375 SC (flusilazole + carbendazim), insecticide - Decis 0.25 EC (deltamethrin), growth retardant - Flordimex 420 SL (ethephon),

b. extensive: harrowing before emergence and at the 3-4 leaf stage, no application of chemical crop protection agents, except for seed dressing - Raxil 060 FS.

All crop protection agents were used on dates and at doses in accordance with recommendations of the Plant Protection Institute in Poznań, Poland. Mineral fertilization of spring barley, both in crop rotation and monoculture, was identical and it was as follows: $\mathrm{N}-60, \mathrm{P}_{2} \mathrm{O}_{5}-70, \mathrm{~K}_{2} \mathrm{O}-90 \mathrm{~kg} \times \mathrm{ha}^{-1}$. Organic fertilization (manure) in crop rotation was applied for potato $\left(35 \mathrm{t} \times \mathrm{ha}^{-1}\right)$, whereas under barley monoculture it was applied once every 3 years $\left(35 \mathrm{t} \times \mathrm{ha}^{-1}\right)$. With respect to the other crop plants grown in crop rotation (potato, horse bean, winter wheat), mechanical treatments and crop protection agents specific for every plant species were also applied. Soil tillage for barley and the other plant species grown in crop rotation followed agricultural practice rules.

The test plants in this experiment were as follows: white mustard in 2007 (cv. Borowska - $20 \mathrm{~kg} \times$ $\left.\mathrm{ha}^{-1}\right)$ and oats in $2008\left(\mathrm{cv}\right.$. Kasztelan $\left.-200 \mathrm{~kg} \times \mathrm{ha}^{-1}\right)$. In the investigated plants, no mineral fertilization or plant protection were used, except for seed dressing (Raxil 069 FS) and intervention treatment with an insecticide in white mustard (Decis 0.25 EC). Such agricultural method (no fertilization and chemical protection) used with respect to the test plants under assessment was designed to enable an objective assessment of the consequent effect of the investigated factors, i.e. crop sequence and crop treatments.

Soil tillage, the quantity and date of sowing of the test plants (white mustard, oats) were within proper agricultural practice standards. The assessment of weed infestation was made using the botanical gravimetric method, during the full growing season of the test plants (mustard - flowering stage, oats - heading stage), thus, during the period of greatest accumulation of biomass by weeds in a canopy. Before weighing, mustard and oats seed yields were brought to the same moisture content level $-14 \%$. The research results were statistically verified, determining the significance of differences using Tukey's test.

\section{RESEARCH RESULTS AND DISCUSSION}

White mustard seed yield was significantly differentiated by the investigated experimental factors (Tab. 1). The cultivation of this plant in the stand after spring barley under the Norfolk crop rotation system resulted in seed yield higher by $51 \%$ than that found in the treatments with the consequent influence of monoculture. The influence of protection method in the spring barley canopy proved to be even more evident. Intensive protection, irrespective of the forecrop, provided mustard seed yield larger by $51 \%$ compared to the extensive protection treatments. The stand after spring barley grown in crop rotation and intensively protected guaranteed the largest white mustard seed yield $\left(1.82 \mathrm{t} \times \mathrm{ha}^{-1}\right)$. The lowest mustard productivity was found in the stand after extensively protected spring barley in monoculture (only $0.71 \mathrm{t} \times \mathrm{ha}^{-1}$ ).

Oats, as the other test plant, showed smaller variations in yields resulting from crop succession (Tab. 1). It can be explained by the fact that white mustard, 
Table 1

The influence of crop rotation, monoculture and spring barley protection method on yields of succeeding crops.

\begin{tabular}{|c|c|c|c|c|c|c|}
\hline \multirow{3}{*}{ Specification } & \multicolumn{6}{|c|}{ Test plants } \\
\hline & \multicolumn{3}{|c|}{ White mustard - seed yield $\left(\mathrm{t} \mathrm{ha}^{-1}\right)$} & \multicolumn{3}{|c|}{ Oats - grain yield $\left(\mathrm{t} \mathrm{ha}^{-1}\right)$} \\
\hline & $\mathrm{PI}^{*}$ & $\mathrm{PE}^{* *}$ & mean & PI & $\mathrm{PE}$ & mean \\
\hline $\begin{array}{l}\text { Spring barley } \\
\text { in crop rotation }\end{array}$ & 1.82 & 0.96 & 1.39 & 3.19 & 2.24 & 2.71 \\
\hline $\begin{array}{l}\text { Spring barley } \\
\text { in monoculture }\end{array}$ & 1.55 & 0.71 & 1.13 & 3.02 & 2.15 & 2.58 \\
\hline Mean & 1.68 & 0.83 & - & 3.10 & 2.19 & - \\
\hline $\begin{array}{l}\mathrm{LSD}_{0.05} \text { for: } \\
\text { crop sequence }= \\
\text { protection method }= \\
\text { interaction: } \\
\text { crop sequence x protection method }\end{array}$ & & & $\begin{array}{l}0.241 \\
0.365 \\
0.319\end{array}$ & & & $\begin{array}{l}\mathrm{ns} \\
0.452 \\
\mathrm{~ns}\end{array}$ \\
\hline
\end{tabular}

$\mathrm{PI}^{*}-$ intensive protection of barley

$\mathrm{PE}^{* *}$ - extensive protection of barley

ns - not significant

Table 2

The influence of crop rotation, monoculture and spring barley protection method on the number of weeds (per $1 \mathrm{~m}^{2}$ ) in a succeeding crop canopy.

\begin{tabular}{|c|c|c|c|c|c|c|}
\hline \multirow{3}{*}{ Specification } & \multicolumn{6}{|c|}{ Test plants } \\
\hline & \multicolumn{3}{|c|}{ White mustard } & \multicolumn{3}{|c|}{ Oats } \\
\hline & $\mathrm{PI}^{*}$ & $\mathrm{PE}^{* *}$ & mean & PI & PE & mean \\
\hline $\begin{array}{l}\text { Spring barley } \\
\text { in crop rotation }\end{array}$ & 94.9 & 122.6 & 108.7 & 68.2 & 116.9 & 92.5 \\
\hline $\begin{array}{l}\text { Spring barley } \\
\text { in monoculture }\end{array}$ & 111.5 & 143.4 & 127.4 & 95.6 & 120.2 & 107.9 \\
\hline Mean & 103.2 & 133.0 & - & 81.9 & 118.5 & - \\
\hline $\begin{array}{l}\mathrm{LSD}_{0.05} \text { for: } \\
\text { crop sequence }= \\
\text { protection method = } \\
\text { interaction: } \\
\text { crop sequence } \mathrm{x} \text { protect }\end{array}$ & & & $\begin{array}{l}15.32 \\
17.67 \\
\\
14.72\end{array}$ & & & $\begin{array}{l}14.73 \\
17.94 \\
13.34\end{array}$ \\
\hline
\end{tabular}

Explanations in Table 1

as the immediate forecrop of oats, simultaneously performed the role of a phytosanitary plant and had a modifying effect on its yielding, to which attention is drawn by some authors ( $\mathrm{P}$ a w $ł$ o w s k i and D e r y $\nmid$ o, 1988; Muraw a et al. 2004). In the treatments with spring barley monoculture, oats yield was smaller only by $5 \%$ compared to crop rotation. But significantly lower productivity of white mustard (by 29\%) in the extensive protection treatments was noted compared to comprehensive (mechanical and chemical) protection.
The number of weeds in the test plant canopies also depended significantly on the investigated factors (Tab. 2). The lowest number of weeds was recorded in the crop rotation with intensive protection, both in the mustard and oats canopy. In the stand after spring barley monoculture, the number of weeds was larger by, respectively, 15\% (mustard) and 14\% (oats) compared to crop rotation. The application of plant protection agents (including herbicides) in spring barley crops, irrespective of crop succession, caused the number 
Table 3

The influence of crop rotation, monoculture and spring barley protection method on air-dry weight of weeds $\left(\mathrm{g} \mathrm{m}^{2}\right)$ in a succeeding crop canopy.

\begin{tabular}{|c|c|c|c|c|c|c|}
\hline \multirow{3}{*}{ Specification } & \multicolumn{6}{|c|}{ Test plants } \\
\hline & \multicolumn{3}{|c|}{ White mustard } & \multicolumn{3}{|c|}{ Oats } \\
\hline & $\mathrm{PI}^{*}$ & $\mathrm{PE}^{* *}$ & mean & PI & $\mathrm{PE}$ & mean \\
\hline $\begin{array}{l}\text { Spring barley } \\
\text { in crop rotation }\end{array}$ & 76.4 & 87.6 & 82.0 & 70.2 & 84.4 & 77.3 \\
\hline $\begin{array}{l}\text { Spring barley } \\
\text { in monoculture }\end{array}$ & 80.9 & 94.8 & 87.8 & 72.8 & 86.9 & 79.8 \\
\hline Mean & 78.6 & 91.2 & - & 71.5 & 85.6 & - \\
\hline $\begin{array}{l}\mathrm{LSD}_{0.05} \text { for: } \\
\text { crop sequence }= \\
\text { protection method = } \\
\text { interaction: } \\
\text { crop sequence } \mathrm{x} \text { protect }\end{array}$ & & & $\begin{array}{l}\mathrm{ns} \\
10.58 \\
\text { ns }\end{array}$ & & & $\begin{array}{l}\text { ns } \\
11.25 \\
\text { ns }\end{array}$ \\
\hline
\end{tabular}

Explanations in Table 1

Table 4

The simple correlation coefficient (r) between air-dry weight of weeds in a canopy and yields of succeeding crops.

\begin{tabular}{ccccccc}
\hline & \multicolumn{5}{c}{ Test plants } \\
\cline { 2 - 6 } Specification & \multicolumn{3}{c}{ White mustard } & Oats \\
\cline { 2 - 6 } & $\mathrm{PI}^{*}$ & $\mathrm{PE}^{* *}$ & mean & $\mathrm{PI}$ & $\mathrm{PE}$ & -0.40 \\
\hline $\begin{array}{c}\text { Spring barley } \\
\text { in crop rotation }\end{array}$ & -0.41 & $-0.75^{*}$ & $-0.58^{*}$ & -0.36 & -0.45 & -0.44 \\
\hline $\begin{array}{c}\text { Spring barley } \\
\text { in monoculture }\end{array}$ & $-0.66^{*}$ & $-0.82^{*}$ & $-0.74^{*}$ & -0.38 & -0.50 & - \\
\hline Mean & $-0.53^{*}$ & $-0.78^{*}$ & - & -0.37 & -0.47 & - \\
\hline
\end{tabular}

Explanations in Table 1

* significant correlation coefficient

of weeds in the intensive protection treatments to be smaller by $22 \%$ (mustard) and $31 \%$ (oats) compared to the extensive protection treatments.

The crop sequence system did not result in any great differences in air-dry weight of weeds in the white mustard and oats canopy (Tab. 3). A tendency towards larger weight of weeds (by $7 \%$ - mustard, 3\% - oats) in monoculture compared to crop rotation was only noted. However, the introduction of the phytosanitary test plants did not compensate the negative consequent influence of extensive protection of the crop canopy. Air-dry weight of weeds determined under such conditions was larger by $14 \%$ (mustard) and 16\% (oats) compared to the treatments in which intensive protection of spring barley was applied. However, it should be noted that the cultivation of phytosanitary crops in successive years eliminated the negative effect of monoculture and extensive protection of the canopy, in particular in the case of weight of weeds in the oats canopy. As a result, the effect of air-dry weight of weeds on oats productivity was similar in particular treatments, which is confirmed by the calculated correlation coefficients (Tab. 4).

In the white mustard canopy, the number of weed species after various forecrops was 24-27, whereas in the oats canopy - 22-24 (Tab. 5). The largest amount of dominant weed species was found in the stand after Norfolk crop rotation (white mustard), whereas the lowest amount in the oats canopy grown after 6-year-long barley monoculture. Chenopodium album, Echinochloa crus-galli, Stellaria media occurred in greatest numbers in the canopy of both test 
Table 5

Dominant weed species in a test plant canopy, irrespective of the protection method.

\begin{tabular}{|c|c|c|c|c|c|c|}
\hline \multirow{3}{*}{ Specification } & \multicolumn{6}{|c|}{ Test plants } \\
\hline & \multicolumn{3}{|c|}{ White mustard } & \multicolumn{3}{|c|}{ Oats } \\
\hline & $\mathrm{Jm}$ & Jp & mean & $\mathrm{Jm}$ & Jp & mean \\
\hline \multicolumn{7}{|c|}{ Number of dominant weed species per $1 \mathrm{~m}^{2}$} \\
\hline 1. Chenopodium album $\mathrm{L}$. & 30.3 & 20.6 & 25.4 & 20.6 & 16.7 & 18.6 \\
\hline 2. Galinsoga parviflora Cav. & 19.7 & 15.2 & 17.4 & 11.3 & 10.4 & 10.8 \\
\hline 3. Echinochloa crus-galli (L.)P. Beauv. & 18.6 & 14.9 & 16.7 & 20.3 & 16.0 & 18.1 \\
\hline 4. Stellaria media (L.) Vill. & 11.3 & 9.8 & 10.5 & 13.4 & 10.2 & 11.8 \\
\hline 5. Polygonum lapathifolium $\mathrm{L}$. & 10.5 & 6.7 & 8.6 & 8.5 & 7.6 & 8.0 \\
\hline 6. Capsella bursa-pastoris (L.) Medik. & 9.9 & 7.4 & 8.6 & 8.4 & 7.9 & 8.1 \\
\hline 7. Elymus repens (L.) Gould & 7.1 & 3.9 & 5.5 & 10.2 & 6.4 & 8.3 \\
\hline 8. Cirsium arvense (L.) Scop. & 6.4 & 6.0 & 6.2 & 7.2 & 7.0 & 7.1 \\
\hline Other species & 13.2 & 23.5 & 18.3 & 8.0 & 10.3 & 9.1 \\
\hline Total number of weeds & 127.4 & 108.7 & 118.0 & 107.9 & 92.5 & 100.2 \\
\hline Number of weed species & 24 & 27 & 25 & 22 & 24 & 23 \\
\hline
\end{tabular}

$\mathrm{Jm}$ - spring barley in monoculture

$\mathrm{Jp}$ - spring barley in crop rotation

plants. Perennial species (Elymus repens, Cirsium arvense) did not pose great threat; nevertheless, their intensified occurrence was found in the oats canopy. Among the short-lived species, the compensation of Echinochloa crus-galli and Stellaria media was also noted. However, the proportions of the other dominant weed species in the oats canopy were reduced: by $27 \%$ (Chenopodium album), 38\% (Galinsoga parviflora) and $50 \%$ (other species not specified in the table).

The results of the present study illustrate that the test plants (mustard, oats) responded by a larger decline in yield to the consequent influence of the absence of chemical protection of spring barley crops than to the negative influence of monoculture. White mustard shows similar yields regardless of the forecrop, due to its resistance to fungal diseases and high ability to compete with weeds. For this reason, it is often sown as a stubble crop in cereal monocultures (O l e s z e k, 1994; K wiatk ow s ki, 2004b). A d a miak and A d a m i a k $(1994,1999)$ note that oats does not show significant differences in yields related to an increased proportion of cereals in a crop rotation. Lower weed infestation of oats and marginal infection by the fungal disease complex determine the great yield-protective importance of this plant.
Yielding of the phytosanitary plants in question was negatively correlated with the level of their weed infestation, which was the highest in the stand after the extensively protected spring barley monoculture (Tab. 4). P a w łow s ki and W e s o łow s ki (1996) demonstrate that quantitative weed infestation of spring barley and of succeeding crops cultivated is determined to a large extent by spring weeds - Chenopodium album, Stellaria media, Poa annua, Echinochloa crus-galli. The regulation of weed population size, and thereby decreasing their competitiveness relative to a crop plant, depends to a large degree on the proper crop sequence. Crop rotation and also some succeeding crops (mustard, oats), thanks to their phytosanitary effect on soil and allelopathic responses, inhibit in a natural way the development of some weeds. D e r y ło (1994) as well as K w i a t k o w s k i and W e s o łow s ki (2004) are of opinion that the application of comprehensive crop protection (foreforecrops) has a significant effect on the limitation of weed infestation of succeeding crops. O le s zek (1994) proves that substances contained in mustard (glucosinolates, isothiocyanates) reduce the population size of weeds such as Chenopodium album, Galium aparine, Matricaria maritima ssp. inodora, 
Capsella bursa-pastoris. Nevertheless, mustard press cakes mixed with soil have the greatest allelopathic effect. Hence, it can be presumed that the weed control activity of this plant in the present study was revealed only after its harvest and the ploughing-in of post-harvest residues and it limited weed infestation of the next crop grown in this stand (oats). J ę drus zczak et al. (2005) note that in years characterised by low temperature and wet weather (May - July), late emerging weeds (Galinsoga parviflora, Echinochloa crus-galli, Gnaphalium uliginosum), being the core of dominant species, occur in greatest numbers in a white mustard canopy. It is attested by the competitiveness of white mustard grown under good soil culture conditions and proper agricultural practice, even without any weed destruction, which finds reflection in the paper in question. In addition, the authors claim that growing white mustard after cereals, on poor soils of low culture, causes increased weed infestation and requires chemical weed control.

In the present study, weeds did not dominate the white mustard canopy. In spite of the absence of chemical protection of the crop, the weight of a single weed, irrespective of the investigated factors, was ca. $0.75 \mathrm{~g}$, on the average, and similar tendencies were also observed in the oats crop. Observations of weed infestation conducted by $\mathrm{A} \mathrm{d} \mathrm{a} \mathrm{m} \mathrm{i} \mathrm{a} \mathrm{k} \mathrm{and} \mathrm{A} \mathrm{d} \mathrm{a} \mathrm{m} \mathrm{i} \mathrm{a} \mathrm{k}$ (1999) showed that the introduction of oats into a crop rotation limited the occurrence of weeds. Oats competed with weeds better than other spring cereal species as well as some leguminous plants (horse bean).

\section{CONCLUSIONS}

1. Spring barley grown in crop rotation and intensively protected showed the most beneficial consequent effect on yields and weed infestation of white mustard and oats. The greatest decline in yields of the test plants was observed in the stand after six-year-long extensively protected monoculture of spring barley

2. The introduction of phytosanitary plants into cultivation over successive two years eliminated the negative influence of barley monoculture, resulting in the level of oats yields and weed infestation similar to that in the stand after crop rotation, but it did not compensate the negative consequences of extensive protection.

3. The cultivation of white mustard, and then oats, irrespective of the investigated factors, in spite of the absence of herbicide application, maintained weed infestation of the canopy at a level which did not create a risk of a dramatic decline in productivity of these crop plants.

4. The following short-lived weed species: Chenopodium album, Galinsoga parviflora and Echinochloa crus-galli, were predominant in the canopy of the test plants. The deprivation of chemical protection of the canopy resulted in intensified occurrence of perennial species (Elymus repens, Cirsium arvense).

\section{REFERENCES}

A d a miak E., 2007. Struktura zachwaszczenia i produktywność wybranych agrocenoz zbóż ozimych i jarych w zależności od systemu następstwa roślin i ochrony łanu. / Weed infestation structure and productivity of chosen winter and spring crop agrocenoses depending on vegetal succession and standing corn protection. Rozprawy i monografie, UW-M w Olsztynie, 129: 146.

Adamiak E., Adamiak J., 1999. Plonotwórcza i plonochronna rola owsa w płodozmianach zbożowych. / The yield-forming and yield-protecting role of oats in cereal crop rotations. Pam. Puł. 114: 15-21.

A d a miak J., 1992. Proportions of cereals in crop rotations. Acta Acad. Agricult. Tech. Olst., Agricultura, 55: 173182.

Ad a miak J., Adamiak E., 1994. Reakcja owsa na udział zbóż w płodozmianie i na monokulturę. / Oats response to the proportions of cereals in crop rotation and monoculture. Zesz. Nauk. ATR Bydgoszcz, Rol., 35: 53-60.

Blecharczyk A., Małecka I., Pudełko J., 2005. Reakcja roślin na monokulturę $\mathrm{w}$ wieloletnim doświadczeniu w Brodach. / Crop response to monoculture in a long-term experiment in Brody. Fragm. Agron. 2 (86): 20-29.

Deryło S., 1994. Następczy wpływ płodozmianów zbożowych na plonowanie i zachwaszczenie roślin uprawnych. / The consequent influence of cereal crop rotations on yielding and weed infestation of crop plants. [In:] Przyczyny i źródła zachwaszczenia pól uprawnych. Wyd. ART Olsztyn, R: 87-94.

Deryło S., Pawłowski F., 1982. Wpływ intensywności pielęgnowania na plonowanie pszenicy ozimej i jęczmienia jarego w płodozmianach o różnym udziale zbóż. / The influence of protection intensity on the yielding of winter wheat and spring barley in crop rotations with various cereal proportions. Ann. UMCS, sect. E, XLVII: $1-5$.

Jelinowski S., 1979. Znaczenie i wartość przedplonowa owsa w zmianowaniach o dużym udziale zbóż. / The significance and forecrop value of oats in crop rotations with high cereal proportions. Zesz. Probl. Post. Nauk Roln. 218: 235-242.

Jędruszczak M., Dąbek-Gad M., Owczarczuk A., 2005. Chwasty w łanie gorczycy białej (Sinapis alba L.) uprawianej na nasiona po różnych zmianowaniach na płowej glebie lessowej. / Weeds in a white mustard (Sinapis alba L.) canopy grown for seeds after different crop rotations on grey-brown podzolic loess soil. Prog. Plant Protect. / Post. Ochr. Roślin, 45 (2): 752-755.

Kw i at kow sk i C., 2004a. Plonowanie i jakość ziarna nagoziarnistej i oplewionej formy jęczmienia jarego w zależ- 
ności od zróżnicowanej ochrony zasiewów. / Yields and quality of grain from naked and husked forms of spring barley depending on various types of crop protection. Pam. Pul. 123: 137-144.

Kw i at kow sk i C., 2004b. Wpływ międzyplonu na plonowanie i zachwaszczenie jęczmienia jarego uprawianego w monokulturze. / The effect of a catch crop on yields and weed infestation of spring barley cultivated in monoculture. Ann. UMCS, sect. E, 59 (2): 809-815.

Kwiat kowski C., We s ołowski M., 2004. Zachwaszczenie jęczmienia jarego $\mathrm{w}$ płodozmianie i monokulturze w zależności od sposobu pielęgnacji łanu. / Weed infestation of spring barley in crop rotation and monoculture depending on methods used for canopy protection. Prog. Plant Protect. / Post. Ochr. Roślin, 44 (2): 917-919.

Murawa D., Pykało I., Banaszkiewicz T., 2004. Kompleksowa ocena chwastobójcza substancji aktywnych w gorczycy białej (Sinapis alba L.). / Comprehensive weed control evaluation of active substances in white mustard (Sinapis alba L.). Rośliny Oleiste XXV: 521-531.

Oleszek W., 1994. Brassicacae jako rośliny alternatywne umożliwiające kontrolę zachwaszczenia w rolnictwie zachowawczym. / Brassicacae as alternative plants used for weed control in sustainable agriculture. Fragm. Agron. 4 (44): 5-19.

Pawłowski F., We sołowski M., 1986. Plonowanie i zachwaszczenie roślin następczych uprawianych po wieloletniej monokulturze jęczmienia jarego. / Yielding and weed infestation of succeeding crops cultivated after long-term monoculture of spring barley. Ann. UMCS, sect. E, 43: 1-9.

Pawłowski F., Deryło S., 1988. Plonowanie i wartość przedplonowa owsa w zmianowaniach o dużej koncentracji zbóż. / Yielding and the forecrop value of oats in crop rotations of high cereal concentration. Zesz. Probl. Post. Nauk Roln. 331: 101-109.

Stupnicka-Rodzynkiewicz E., Stępnik K., Lepiarczyk A., 2004. Wpływ zmianowania, sposobu uprawy roli i herbicydów na bioróżnorodność zbiorowisk chwastów. / Effect of crop rotation, tillage method and herbicides on the biodiversity of weed communities. Acta Sci. Pol., Agricultura 3 (2): 235-245.

We sołowski M., Kwiatkowski C., Stępień A., 2003. Wpływ mieszanek międzyodmianowych jęczmienia jarego na zachwaszczenie tej rośliny w uprawie monokulturowej i płodozmianie. / Influence of inter-variety mixtures of spring barley on weed infestation in monocultural and crop rotation cultivation of this plant. Acta Agrophysica, 1 (4): 795-802.

Z aw iśla k K., 1997. Regulacyjna funkcja płodozmianu wobec chwastów w agrofitocenozach zbóż. / The regulating function of crop rotation in relation to weeds in cereal agrophytocenoses. Acta Acad. Agricult. Tech. Olst. 64: 81-99.

\section{Następczy wpływ płodozmianu i sześcioletniej monokultury jęczmienia jarego na plonowanie oraz zachwaszczenie gorczycy białej i owsa}

\section{Streszczenie}

Badania przeprowadzono w latach 2007-2008, po 6-letnich doświadczeniach z uprawą jęczmienia jarego w płodozmianie i monokulturze. Drugim czynnikiem eksperymentu był sposób pielęgnacji jęczmienia jarego. Intensywna pielęgnacja polegała na kompleksowej ochronie jęczmienia (bronowanie zasiewów, zaprawianie nasion, stosowanie herbicydów, fungicydów, retardanta i insektycydu). Ekstensywna pielęgnacja sprowadzała się tylko do bronowania zasiewów, bez stosowania środków ochrony roślin, poza zaprawą nasienną. Powyższe czynniki były tłem badań $\mathrm{z}$ uprawą w kolejnych latach gorczycy białej i owsa, jako gatunków fitosanitarnych. W roślinach testowych nie stosowano nawożenia mineralnego i ochrony roślin. Taki sposób agrotechniki umożliwiał obiektywną ocenę następczego oddziaływania monokultury, płodozmianu i zabiegów pielęgnacyjnych. Przyjęto hipotezę, że uprawa roślin fitosanitarnych w stanowisku po 6-letniej monokulturze jęczmienia pozwoli na uzyskanie poziomu plonów i zachwaszczenia zbliżonego do obiektów płodozmianu. Założono również, że uprawa gorczycy białej i owsa zniweluje różnice w produkcyjności roślin spowodowane negatywnym wpływem ekstensywnej pielęgnacji.

Dowiedziono, że uprawa roślin fitosanitarnych niwelowała negatywny wpływ monokultury na poziom ich plonowania i zachwaszczenia. Rośliny testowe nie kompensowały jednak ujemnych następstw ekstensywnej pielęgnacji. Pomimo tego, gorczyca biała i owies skutecznie konkurowały z chwastami, a liczba i masa chwastów w łanie nie powodowały gwałtownego spadku plonów. W łanie roślin testowych dominowały chwasty krótkotrwałe: Chenopodium album, $\mathrm{Ga}$ linsoga parviflora, Echinochloa crus-galli. Brak stosowania herbicydów skutkował kompensacją gatunków wieloletnich: Elymus repens i Cirsium arvense. 